\title{
Validasi Metode Pendugaan Umur Simpan Produk Pangan Renyah dengan Metode Kadar Air Kritis
}

\section{Validation Method of Shelf Life Estimation of Dry Crisp Food Products by Using Critical Moisture Content Method}

\author{
Novi Alfiyani ${ }^{1}$, Nur Wulandari ${ }^{1,2)^{*}}$, Dede R. Adawiyah ${ }^{1,2)}$ \\ ${ }^{1)}$ Departemen Ilmu dan Teknologi Pangan, Fakultas Teknologi Pertanian, Institut Pertanian Bogor, Bogor \\ ${ }^{2}$ South East Asian Food and Agricultural Science and Technology Center, Institut Pertanian Bogor, Bogor
}

\begin{abstract}
Shelf life of food products is one of the most important information listed on food packaging labels. A dry crisp food product has a relatively long shelf life with sogginess as damage parameters. This research is aimed to obtain a validated procedure for shelf life estimation of dry crisp food products by critical moisture content method, so it can be used as a standard procedure in shelf life estimation. The research was conducted with seven repetitions by using potato chips as food model and it started by determination of initial moisture content, critical moisture content, weight of dry food solids, other variables, and determination of MSI curve of GAB model to obtain slope $b$ and equilibrium moisture content. Shelf life was calculated by using Labuza's Equation, then shelf life data obtained and the parameters affecting it, were validated by using precision criteria based on Relative Standard Deviation (RSD) less than 2/3 RSDH (Horwitz equation) value. The result showed that both of shelf life data and all affecting parameters, has been validated. Shelf life at 75 and $80 \%$ RH were $22.21 \pm 0.08$ months and $11.44 \pm 0.08$ months, RSD value were 0.37 and $0.74 \%$, as well as $2 / 3$ RSDH value were 0.84 and $0.92 \%$ respectively. Thus, it can be concluded that procedure of shelf life estimation of dry crisp food products by using critical moisture content method was a valid and an appropriate method for its purpose, and can produce accurate shelf life calculation.
\end{abstract}

Keywords: critical moisture content method, dry crisp food product, Labuza's equation, method validation, shelf life

\begin{abstract}
Abstrak. Umur simpan produk pangan merupakan salah satu informasi yang penting dicantumkan pada label kemasan pangan. Produk pangan kering yang renyah memiliki umur simpan yang relatif lama dengan parameter kerusakan berupa penurunan kerenyahan. Penelitian ini dilakukan untuk memperoleh prosedur pendugaan umur simpan produk pangan renyah dengan metode kadar air kritis yang tervalidasi sehingga dapat digunakan secara tetap dan baku dalam analisis pendugaan umur simpannya. Penelitian dilakukan sebanyak tujuh kali ulangan menggunakan model pangan berupa keripik kentang yang diawali dengan penentuan kadar air awal, kadar air kritis, bobot padatan per kemasan, variabel lain, serta penentuan kurva ISA model GAB untuk memperoleh slope b dan kadar air kesetimbangan. Umur simpan dihitung berdasarkan persamaan Labuza, dimana hasil perhitungan umur simpan dan parameter yang memengaruhinya, divalidasi ketepatannya dengan kriteria presisi berdasarkan nilai RSD yang lebih kecil dari 2/3 RSDH. Hasil penelitian menunjukkan bahwa seluruh parameter serta perhitungan umur simpan, telah tervalidasi dengan umur simpan pada RH 75 dan $80 \%$ berturut-turut sebesar $22.21 \pm 0.08$ dan $11.44 \pm 0.08$ bulan, nilai RSD 0.37 dan $0.74 \%$, serta nilai $2 / 3$ RSDH 0.84 dan $0.92 \%$. Dengan demikian dapat disimpulkan bahwa prosedur pendugaan umur simpan produk pangan renyah dengan metode kadar air kritis merupakan metode yang valid dan sesuai untuk tujuannya, serta dapat menghasilkan perhitungan umur simpan yang akurat.
\end{abstract}

Kata Kunci: metode kadar air kritis, produk pangan renyah, persamaan Labuza, umur simpan, validasi metode

Aplikasi Praktis: Umur simpan merupakan informasi yang penting dalam label kemasan pangan. Metode
pendugaan umur simpan produk pangan renyah berdasarkan metode kadar air kritis yang tervalidasi sangat
diperlukan untuk menjamin validitas data umur simpan yang dihasilkan, sehingga prosedur tersebut dapat
digunakan secara baku, serta mampu memberikan hasil perhitungan umur simpan yang tepat dan akurat.

\section{PENDAHULUAN}

Umur simpan produk pangan merupakan informasi sangat penting dicantumkan pada label kemasan pangan.
Berdasarkan UU Pangan No. 18 tahun 2012 dan PP No. 69 tahun 1999 tentang Label dan Iklan Pangan, setiap industri pangan wajib mencantumkan tanggal kedaluwarsa pada kemasan produk. Menurut Kilcast dan

Korespondensi: wulandari_safardan@yahoo.com 
Subramaniam (2000), umur simpan produk pangan merupakan selang waktu produk pangan berada dalam kondisi aman dengan mempertahankan karakter sensori, kimia, fisik, serta mikrobiologi yang diinginkan serta memenuhi nilai gizi yang tercantum pada label kemasan.

Metode kadar air kritis merupakan salah satu metode ASLT (Accelerated Shelf Life Testing) pendugaan umur simpan produk pangan yang sensitif terhadap penyerapan uap air. Produk pangan renyah bersifat sensitif terhadap penyerapan uap air dengan kerenyahan sebagai parameter mutunya (Kwak et al. 2015). Kadar air dan $\mathrm{a}_{\mathrm{w}}$ rendah menyebabkan tekstur produk pangan renyah dengan umur simpan panjang (Sakac et al. 2016). Pendugaan umur simpan produk sensitif terhadap penyerapan uap air dilakukan dengan metode kadar air kritis yang mensimulasi kerusakan akibat penyerapan uap air oleh produk dengan mengetahui polanya (Aini et al. 2014).

Umur simpan produk pangan metode kadar air kritis dihitung menggunakan persamaan Labuza dengan mengetahui nilai kadar air awal, kadar air kritis, konstanta permeabilitas uap air, dan luas permukaan kemasan, bobot padatan per kemasan, tekanan uap jenuh, dan parameter kurva isotermi sorpsi air (ISA) yang terdiri dari slope b dan kadar air kesetimbangan (Labuza 1982). Untuk mendapatkan kurva ISA kadar air kesetimbangan pada berbagai nilai $a_{w}$, model GAB (Guggenheim, Anderson, de Boer) menggambarkan pola penyerapan uap air kisaran $\mathrm{a}_{\mathrm{w}}$ luas yaitu 0-0.9 (Andrade et al. 2011).

Untuk menghasilkan data umur simpan akurat sesuai karakteristik produk, perlu dilakukan metode yang sudah tetap, baku, dan tervalidasi. Namun metode SNI maupun AOAC belum menetapkan metode penentuan umur simpan produk pangan baku. Sehingga validasi metode pendugaan berdasarkan metode kadar air kritis perlu dilakukan untuk menjamin validitas data umur simpan.

Tahap validasi metode bertujuan mengukur performa data perhitungan umur simpan dengan metode kadar air kritis untuk pangan renyah, yang dalam penelitian menggunakan model pangan renyah berupa keripik kentang. Uji validitas dilakukan sebanyak tujuh kali ulangan dengan analisis triplo tiap ulangan, parameter validasi metode yang dianalisis yaitu keseksamaan atau presisi data (Harmita 2004). Validasi presisi dilakukan terhadap seluruh parameter dan hasil perhitungan umur simpan. Hasil analisis memenuhi kriteria presisi apabila menghasilkan nilai RSD $\leq 2 / 3$ RSDH (ICH 2005).

Tujuan validasi metode adalah membuktikan bahwa prosedur pendugaan umur simpan dengan metode kadar air kritis, merupakan metode valid dan sesuai, sehingga dapat digunakan secara baku dan tetap untuk menduga umur simpan produk pangan renyah. Penelitian mengenai validasi metode pendugaan umur simpan dengan metode kadar air kritis diharapkan dapat menjamin ketepatan prosedur analisis karakteristik produk, memperoleh metode analisis yang cepat dan ekonomis, serta memberikan hasil perhitungan umur simpan yang akurat.

\section{BAHAN DAN METODE}

\section{Bahan}

Bahan yang digunakan adalah keripik kentang komersial dengan tanggal dan kode produksi sama, $\mathrm{NaOH}, \mathrm{K}$-asetat, $\mathrm{MgCl}_{2}, \mathrm{NaBr}, \mathrm{KI}, \mathrm{NaCl}, \mathrm{KBr}$, akuades. Alat yang digunakan adalah cawan aluminium, pencapit logam, oven listrik, neraca analitik, mortar, kemasan mettalized plastic, hand sealer, desikator, box $34 \times 26 \times 7$ $\mathrm{cm}^{3}$, penyangga dari ram kawat $32.5 \times 25.5 \times 3 \mathrm{~cm}^{3}$.

\section{Metode}

Penelitian diawali analisis penentuan parameter yang memengaruhi perhitungan umur simpan sebanyak tujuh kali ulangan, dengan analisis triplo. Umur simpan keripik kentang dihitung berdasarkan persamaan Labuza. Validasi metode dengan menghitung kriteria presisi dari parameter dan perhitungan umur simpan keripik kentang.

\section{Pengukuran kadar air awal}

Kadar air awal $\left(\mathrm{m}_{\mathrm{o}}\right)$ keripik kentang dianalisis dengan metode SNI 01-2891-1992 (BSN 1992) tujuh kali ulangan terhadap tujuh sampel kemasan berbeda yang diperkecil dan dianalisis triplo setiap ulangan. Hasil kadar air dinyatakan $\mathrm{g} \mathrm{H}_{2} \mathrm{O} / \mathrm{g}$ padatan (basis kering).

\section{Penentuan bobot padatan per kemasan}

Bobot padatan per kemasan $\left(\mathrm{W}_{\mathrm{s}}\right)$ dinyatakan sebagai g padatan per kemasan dan dihitung berdasarkan rumus:

$\%$ padatan $=(1-$ kadar air basis basah $) \times 100 \%$

Bobot padatan per kemasan (g)

$=$ Bobot sampel per kemasan $(\mathrm{g}) \mathrm{x} \%$ padatan

\section{Penentuan kadar air kritis}

Kadar air kritis $\left(m_{c}\right)$ dengan menyimpan sampel selama 0, 30, 45, 60, 90, dan 120 menit tanpa kemasan pada wadah tertutup, dilengkapi penyangga dan diisi air 2 L (Gambar 1) agar penurunan kerenyahan lebih cepat $\left(\mathrm{RH}\right.$ air $100 \%$ setara $\mathrm{a}_{\mathrm{w}}=1$ ). Proses ini menghasilkan seri sampel dengan waktu penyimpanan berbeda, sampel dikemas kembali untuk uji organoleptik rating intensitas oleh delapan panelis dengan parameter kerenyahan.

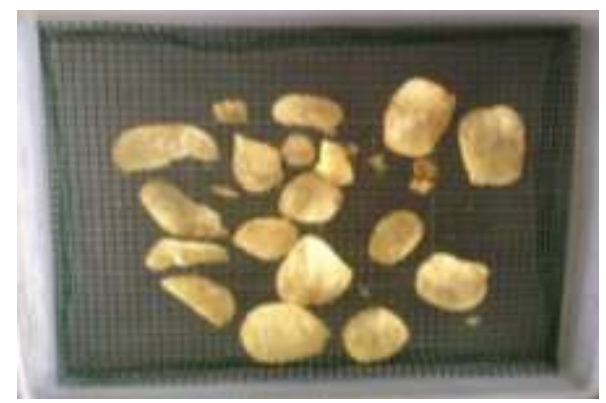

Gambar 1. Wadah penyimpanan bertutup yang digunakan dalam penelitian 
Uji organoleptik dilakukan secara Forum Group Discussion (FGD) dengan pengambilan suara (voting) menentukan sampel yang kerenyahannya tidak diterima lagi. Waktu penyimpanan yang menyebabkan kerenyahannya tidak diterima lagi oleh panelis, dijadikan sebagai dasar persiapan sampel untuk dianalisis kadar airnya dan ditetapkan sebagai kadar air kritis.

\section{Penentuan model kurva isotermi sorpsi air}

Kurva ISA ditentukan sebanyak tujuh kali ulangan dengan sampel 2 g pada cawan aluminium (triplo), kemudian diletakkan pada tujuh desikator berisi larutan garam jenuh berbeda (Tabel 1).

Tabel 1. Nilai ERH larutan garam jenuh pada suhu $30^{\circ} \mathrm{C}$

\begin{tabular}{lc}
\multicolumn{1}{c}{ Larutan Garam Jenuh } & ERH (\%) \\
\hline $\mathrm{NaOH}$ & 7.58 \\
$\mathrm{Kalium}$ asetat & 21.61 \\
$\mathrm{MgCl}_{2}$ & 32.44 \\
$\mathrm{NaBr}$ & 56.03 \\
$\mathrm{KI}$ & 67.89 \\
$\mathrm{NaCl}$ & 75.09 \\
$\mathrm{KBr}$ & 80.27 \\
\hline
\end{tabular}

Sampel ditimbang setiap hari hingga tercapai bobot konstan (selisih tiga kali penimbangan $<2 \mathrm{mg} / \mathrm{g}$ untuk $\mathrm{RH}<90 \%$, dan $<10 \mathrm{mg} / \mathrm{g}$ untuk RH $>90 \%$ ), diukur kadar airnya dan dinyatakan sebagai kadar air kesetimbangan (Me) hasil percobaan, yang kemudian diubah menjadi Me GAB. Persamaan kuadratik model GAB diperoleh dari kurva hubungan $\mathrm{a}_{\mathrm{w}}$ dengan $\mathrm{a}_{\mathrm{w}} / \mathrm{Me}$, dinyatakan sebagai:

$$
\begin{gathered}
y=\alpha x^{2}+\beta x+\gamma \\
a_{w} / M_{e}=\alpha \cdot\left(a_{w}\right)^{2}+\beta \cdot a_{w}+\gamma
\end{gathered}
$$

Nilai Me GAB dihitung berdasarkan rumus:

$$
M e=\frac{X_{m} \cdot C \cdot K \cdot a_{w}}{\left(1-K \cdot a_{w}\right)\left(1-K \cdot a_{w}+C \cdot K \cdot a_{w}\right)}
$$

Keterangan: Me: Kadar air kesetimbangan perhitungan model GAB (basis kering); $\mathrm{a}_{\mathrm{w}}$ : Aktivitas air; $\mathrm{X}_{\mathrm{m}}$ : Kadar air kesetimbangan monolayer; K: Konstanta; C: Konstanta energi.

Kurva ISA percobaan dan model GAB dibuat dengan memplotkan Me dan $a_{w}$, kemudian diuji ketepatannya untuk mengetahui ketepatan model dalam menggambarkan keseluruhan kurva ISA dengan menghitung nilai Mean Relative Determination (MRD) (Goula et al. 2008), yaitu:

$$
\mathrm{MRD}=\frac{100}{\mathrm{n}} \sum_{\mathrm{i}-1}^{\mathrm{n}} \frac{\mathrm{Mi}-\mathrm{Mpi}}{\mathrm{Mi}}
$$

Keterangan: Mi: Kadar air kesetimbangan percobaan; Mpi: Kadar air kesetimbangan perhitungan model GAB; n: Jumlah data.

\section{Penentuan kadar air kesetimbangan}

Nilai kadar air kesetimbangan $\left(\mathrm{m}_{\mathrm{e}}\right)$ pada persamaan Labuza dihitung berdasarkan persamaan kuadratik kurva ISA model GAB dengan memasukkan nilai RH 75 dan $80 \%\left(\mathrm{RH} 100 \%\right.$ setara dengan $\left.\mathrm{a}_{\mathrm{w}}=1\right)$ sebagai nilai $\mathrm{x}$.

\section{Penentuan slope b}

Nilai slope diperoleh dari daerah linear kurva ISA model GAB, yaitu garis lurus yang menghubungkan kadar air awal hingga mencapai kadar air kritis, persamaan $y=a+b x$ dengan $b$ sebagai slope.

\section{Informasi variabel lain}

Variabel lain yaitu luas kemasan (A) yang diukur sebagai luasan total kedua sisi kemasan, tekanan uap jenuh $\left(\mathrm{P}_{\mathrm{o}}\right)$ pada suhu penyimpanan berdasarkan tabel tekanan uap air jenuh (Bell dan Labuza 2000), dan permeabilitas kemasan $(\mathrm{k} / \mathrm{x})$ berdasarkan literatur penggunaan kemasan metalized plastic.

\section{Pendugaan umur simpan}

Umur simpan dihitung berdasarkan persamaan Labuza (Labuza 1982) dengan asumsi kondisi penyimpanan pada RH 75 dan $80 \%$, yaitu:

$$
\theta=\frac{\ln \frac{\left(\mathrm{m}_{\mathrm{e}}-\mathrm{m}_{\mathrm{o}}\right)}{\left(\mathrm{m}_{\mathrm{e}}-\mathrm{m}_{\mathrm{c}}\right)}}{\frac{\mathrm{k}}{\mathrm{x}} \times \frac{\mathrm{A}}{\mathrm{W}_{\mathrm{s}}} \times \frac{\mathrm{Po}}{\mathrm{b}}}
$$

Keterangan: Waktu perkiraan umur simpan (hari); me: Kadar air kesetimbangan $\mathrm{g} \mathrm{H}_{2} \mathrm{O} / \mathrm{g}$ padatan); $\mathrm{m}_{\mathrm{o}}$ : Kadar air awal $\left(\mathrm{g} \mathrm{H}_{2} \mathrm{O} / \mathrm{g}\right.$ padatan); mc: Kadar air kritis ( $\mathrm{g} \mathrm{H}_{2} \mathrm{O} / \mathrm{g}$ padatan); k/x: Konstanta permeabilitas uap air kemasan $\left(\mathrm{g} / \mathrm{m}^{2}\right.$.hari.mmHg); A: Luas permukaan kemasan $\left(\mathrm{m}^{2}\right)$; $\mathrm{W}_{\mathrm{s}}$ : Bobot padatan per kemasan $(\mathrm{g})$; $\mathrm{P}_{\mathrm{o}}$ : Tekanan uap jenuh (mmHg); b: Slope kurva ISA.

\section{Validasi metode analisis}

Tahap validasi metode bertujuan mengukur performa data seluruh parameter dan perhitungan umur simpan yang diperoleh, berdasarkan kriteria presisi yang dinyatakan sebagai simpangan baku relatif (RSD). Hasil analisis memenuhi kriteria presisi apabila perhitungan data menghasilkan nilai RSD RSD $\leq 2 / 3 \mathrm{RSDH}$ ( ICH 2005). Nilai RSDA dan RSDH dihitung sebagai:

$$
\begin{aligned}
\mathrm{SD} & =\sqrt{\frac{\sum(\mathrm{x}-\overline{\mathrm{x}})^{2}}{\mathrm{n}-1}} \\
\operatorname{RSDA}(\%) & =\frac{\mathrm{SD}}{\overline{\mathrm{x}}} \times 100 \% \\
\mathrm{RSDH} & =2^{(1-0.5 \log \mathrm{c})}
\end{aligned}
$$

Keterangan: x: Nilai setiap ulangan; $\bar{x}$ : Nilai rata-rata; n: Jumlah sampel; SD: Simpangan baku; RSDA: Simpangan baku relatif; RSDH: Koefisien Horwitz; c: Nilai yang dinyatakan sebagai fraksi desimal.

\section{HASIL DAN PEMBAHASAN}

Penentuan umur simpan produk pangan berupa keripik kentang dilakukan menggunakan persamaan Labuza, dengan terlebih dahulu ditentukan parameter kadar air awal, bobot padatan per kemasan, kadar air kritis, kurva ISA, parameter kurva ISA yang terdiri dari slope b dan kadar air kesetimbangan, serta variabel lain berupa konstanta permeabilitas uap air, luas permukaan kemasan, dan tekanan uap jenuh. 


\section{Parameter persamaan labuza}

Kadar air merupakan faktor utama yang memengaruhi mutu keripik kentang karena mudah mengalami perubahan terhadap RH lingkungannya selama penyimpanan (Herawati 2008). Kadar air awal $\left(\mathrm{m}_{\mathrm{o}}\right)$ keripik kentang basis kering $0.0186 \pm 0.0003 \mathrm{~g} \mathrm{H}_{2} \mathrm{O} / \mathrm{g}$ padatan atau $1.83 \%$ basis basah, yang berada pada kisaran $\mathrm{a}_{\mathrm{w}}$ $0.07-0.08$ berdasarkan kurva ISA keripik kentang model GAB. Tunick et al. (2013) menyatakan produk pangan renyah memiliki $\mathrm{a}_{\mathrm{w}}<0.1$. Hasil penelitian menunjukkan kadar air keripik kentang masih memenuhi syarat mutu SNI 01-4031-1996 (BSN 1996) maksimal 3\% basis basah. Berdasarkan beberapa penelitian, kadar air keripik pisang 2.6 dan 5\% (Manikantan et al. 2012, Borah dan Nayak 2013), keripik singkong 1.3\% (Segovia et al. 2016), keripik ubi 1.25\% (Meher dan Nayak 2015), keripik kentang $1.72 \%$ (Yang et al. 2017), tortilla $2.48 \%$ (Budijanto et al. 2010), biskuit 1.6\% (Romani et al. 2014), kerupuk melinjo 3.61\% (Lestari dan Muharfiza 2015), rengginang 9.67\% (Khalishi 2011), dan kerupuk ikan 4.99-8.81\% (Zulfahmi et al. 2014). Hal ini menunjukkan bahwa produk pangan renyah, termasuk keripik kentang, umumnya memiliki kadar air 1-5\%, dimana batas maksimal kandungannya diatur dalam SNI masing-masing produk pangan renyah.

Bobot keripik kentang per kemasan diketahui sebesar $68 \mathrm{~g}$ sehingga diketahui bobot padatan per kemasan $\left(\mathrm{W}_{\mathrm{s}}\right)$ sebesar $66.7572 \pm 0.0199 \mathrm{~g}$ ( $>90 \%$ padatan). Jumlah padatan ini sudah cukup memberikan tekstur renyah pada keripik kentang dimana tekstur renyah diperoleh apabila bobot padatannya lebih dari 25\% (Setyawan et al. 2013).

Kadar air kritis $\left(\mathrm{m}_{\mathrm{c}}\right)$ merupakan kadar air dimana produk pangan mengalami penurunan mutu sehingga tidak dapat diterima konsumen secara organoleptik (Kusnandar et al. 2010). Berdasarkan uji organoleptik secara FGD, diketahui sampel mencapai kondisi kritis saat disimpan selama 60 menit pada wadah penyimpanan tertutup berisi air. Rata-rata $\mathrm{m}_{\mathrm{c}}$ sampel tujuh kali ulangan yaitu $0.1009 \pm 0.0003 \mathrm{~g} \mathrm{H}_{2} \mathrm{O} / \mathrm{g}$ padatan (Tabel 2), menunjukkan bahwa sampel sudah tidak diterima konsumen secara organoleptik. Nilai $\mathrm{m}_{\mathrm{c}}$ tercapai pada $\mathrm{a}_{\mathrm{w}}$ 0.72 berdasarkan kurva ISA keripik kentang model GAB. Menurut beberapa penelitian, diketahui $\mathrm{m}_{\mathrm{c}}$ keripik apel $0.158 \mathrm{~g} \mathrm{H}_{2} \mathrm{O} / \mathrm{g}$ padatan pada $\mathrm{a}_{\mathrm{w}} 0.5$ (Velickova et al. 2014), dan $\mathrm{m}_{\mathrm{c}}$ kukis $6 \%$ pada $\mathrm{a}_{\mathrm{w}} 0.54$ (Widjajaseputra 2012). Menurut Tunick et al. (2013), produk pangan kehilangan kerenyahannya pada $\mathrm{a}_{\mathrm{w}}$ 0.5-0.6. Kreker, popcorn, dan keripik kentang kehilangan kerenyahannya pada $\mathrm{a}_{\mathrm{w}}$ 0.35-0.50 Jakubczyk et al. (2008).

Nilai $a_{w}$ produk pangan renyah kehilangan kerenyahannya tergantung karakteristik produknya. Penentuan $\mathrm{m}_{\mathrm{c}}$ dilakukan dengan menyimpan sampel pada kondisi RH tinggi dalam waktu berbeda. Pada beberapa penelitian, $m_{c}$ ditentukan dengan menyimpan sampel pada beberapa RH dan suhu. Namun metode tersebut kurang efisien karena membutuhkan banyak desikator berisi larutan garam jenuh berbeda, serta waktu pengujian yang lama hingga mutu sampel menurun selama penyimpanan. Dalam penelitian ini, $m_{c}$ ditentukan dengan menyimpan sampel pada wadah penyimpanan berisi air (RH air 100\%) sehingga kerusakan produk lebih cepat tercapai, dan teknis pelaksanaanya lebih efisien.

Kurva ISA menggambarkan kandungan air produk pangan sebagai keadaan $\mathrm{RH}$, sehingga memperoleh informasi perpindahan uap air selama penyimpanan (Wijaya et al. 2014). Kurva ISA keripik kentang hasil percobaan dan model GAB berbentuk sigmoid dan saling berhimpitan satu sama lain (Gambar 2). Model GAB menggambarkan fenomena sorpsi isotermi sampel keripik kentang secara tepat (Hutasoit 2009). Ketepatan kurva ISA model GAB didukung data MRD tujuh kali ulangan sebesar 5.55, model yang baik bernilai $M R D<10$ (Akoy dan Horsten 2013). Model GAB menggambarkan kurva ISA kreker (Irpatrawan 2009), biskuit (Panjagari et al. 2015), coklat bubuk sereal (Delgado dan Silva 2010), tepung talas (Nurtama dan Lin 2010), yogurt bubuk (Koc et al. 2010), dan koya ikan (Anandito et al. 2017).

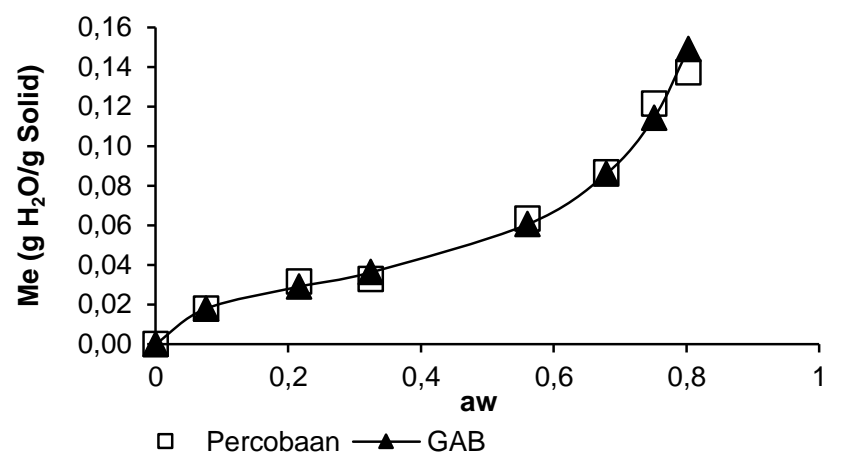

Gambar 2. Kurva ISA keripik kentang hasil percobaan dan model GAB

Tabel 2. Data analisis parameter serta perhitungan umur simpan tujuh kali ulangan

\begin{tabular}{|c|c|c|c|c|c|c|c|c|}
\hline \multirow[t]{2}{*}{ Parameter } & \multirow{2}{*}{$\begin{array}{c}\text { Ka Awal } \\
\text { (g H }{ }_{2} \mathrm{O} / \mathrm{g} \text { Solid) }\end{array}$} & \multirow{2}{*}{$\begin{array}{c}\text { Ka Kritis } \\
\text { (g H } \mathrm{H}_{2} \mathrm{O} / \mathrm{g} \text { Solid) }\end{array}$} & \multirow{2}{*}{$\begin{array}{c}\text { Bobot Padatan } \\
\text { per Kemasan (g) }\end{array}$} & \multirow{2}{*}{$\begin{array}{c}\text { Slope } \\
\text { b }\end{array}$} & \multirow{2}{*}{$\begin{array}{c}\text { Me } \\
\text { RH } 75 \%\end{array}$} & \multirow{2}{*}{$\begin{array}{c}\text { Me } \\
\text { RH } 80 \%\end{array}$} & \multicolumn{2}{|c|}{$\begin{array}{l}\text { Umur Simpan } \\
\text { (Bulan) }\end{array}$} \\
\hline & & & & & & & RH 75\% & RH $80 \%$ \\
\hline 1 & 0.0181 & 0.1009 & 66.7902 & 0.1223 & 0.1138 & 0.1475 & 22.23 & 11.33 \\
\hline 2 & 0.0185 & 0.1008 & 66.7651 & 0.1226 & 0.1139 & 0.1472 & 22.08 & 11.52 \\
\hline 3 & 0.0185 & 0.1007 & 66.7661 & 0.1228 & 0.1136 & 0.1460 & 22.25 & 11.53 \\
\hline 4 & 0.0188 & 0.1013 & 66.7421 & 0.1220 & 0.1141 & 0.1473 & 22.20 & 11.36 \\
\hline 5 & 0.0187 & 0.1005 & 66.7497 & 0.1240 & 0.1137 & 0.1464 & 22.19 & 11.51 \\
\hline 6 & 0.0191 & 0.1011 & 66.7278 & 0.1230 & 0.1141 & 0.1474 & 22.17 & 11.37 \\
\hline 7 & 0.0186 & 0.1008 & 66.7593 & 0.1213 & 0.1132 & 0.1456 & 22.35 & 11.47 \\
\hline$\overline{\mathrm{X}}$ & 0.0186 & 0.1009 & 66.7572 & 0.1226 & 0.1138 & 0.1468 & 22.21 & 11.44 \\
\hline SD & 0.0003 & 0.0003 & 0.0199 & 0.0008 & 0.0003 & 0.0008 & 0.08 & 0.08 \\
\hline RSD (\%) & 1.63 & 0.32 & 0.03 & 0.69 & 0.27 & 0.53 & 0.37 & 0.74 \\
\hline 2/3 RSDH (\%) & 2.43 & 1.94 & 0.71 & 1.83 & 1.85 & 1.78 & 0.84 & 0.92 \\
\hline
\end{tabular}




\section{Kadar air kesetimbangan}

Kadar air kesetimbangan $\left(m_{e}\right)$ merupakan kadar air ketika tekanan uap air produk dalam kondisi setimbang dengan lingkungan (bobot produk konstan), berdasarkan percobaan untuk mendapatkan kurva ISA produk pangan (Lutovska et al. 2017). Nilai $\mathrm{m}_{\mathrm{e}}$ persamaan Labuza ditentukan pada RH 75 dan 80\% (Tabel 2), diasumsikan sebagai RH penyimpanan sampel. Nilai $m_{e}$ RH $80 \%$ lebih besar dibanding RH 75\%, sampel mengalami adsorpsi dengan karakteristik penyerapan uap air lebih tinggi seiring tingginya $\mathrm{RH}$ penyimpanan.

\section{Slope b}

Berdasarkan persamaan regresi linear kurva ISA tujuh ulangan (Gambar 3), nilai rata-rata slope b sebesar $0.1226 \pm 0.0008$. Penentuan slope berdasarkan Bell dan Labuza (2000), slope kurva ISA diperoleh dari garis lurus yang menghubungkan kadar air awal dan kadar air kritis.

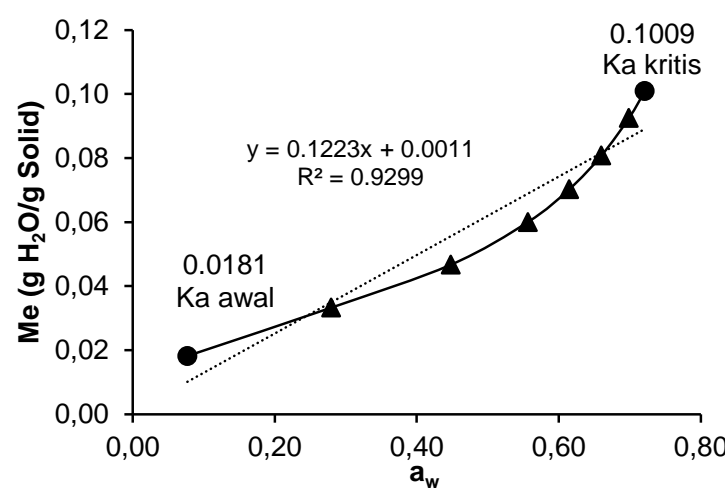

A

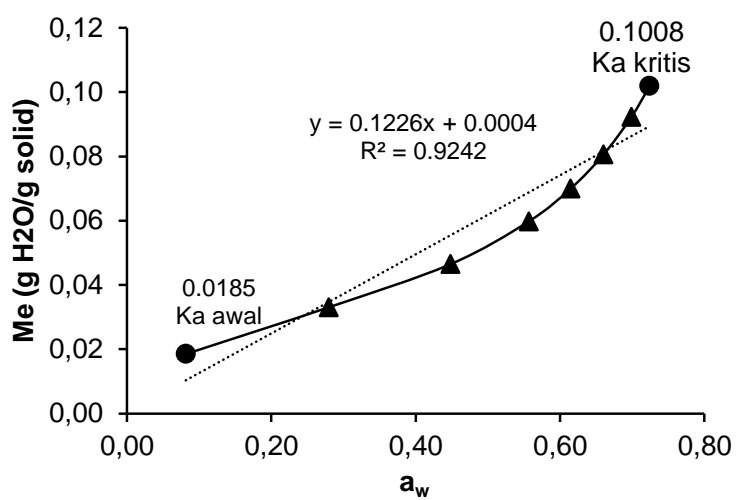

B
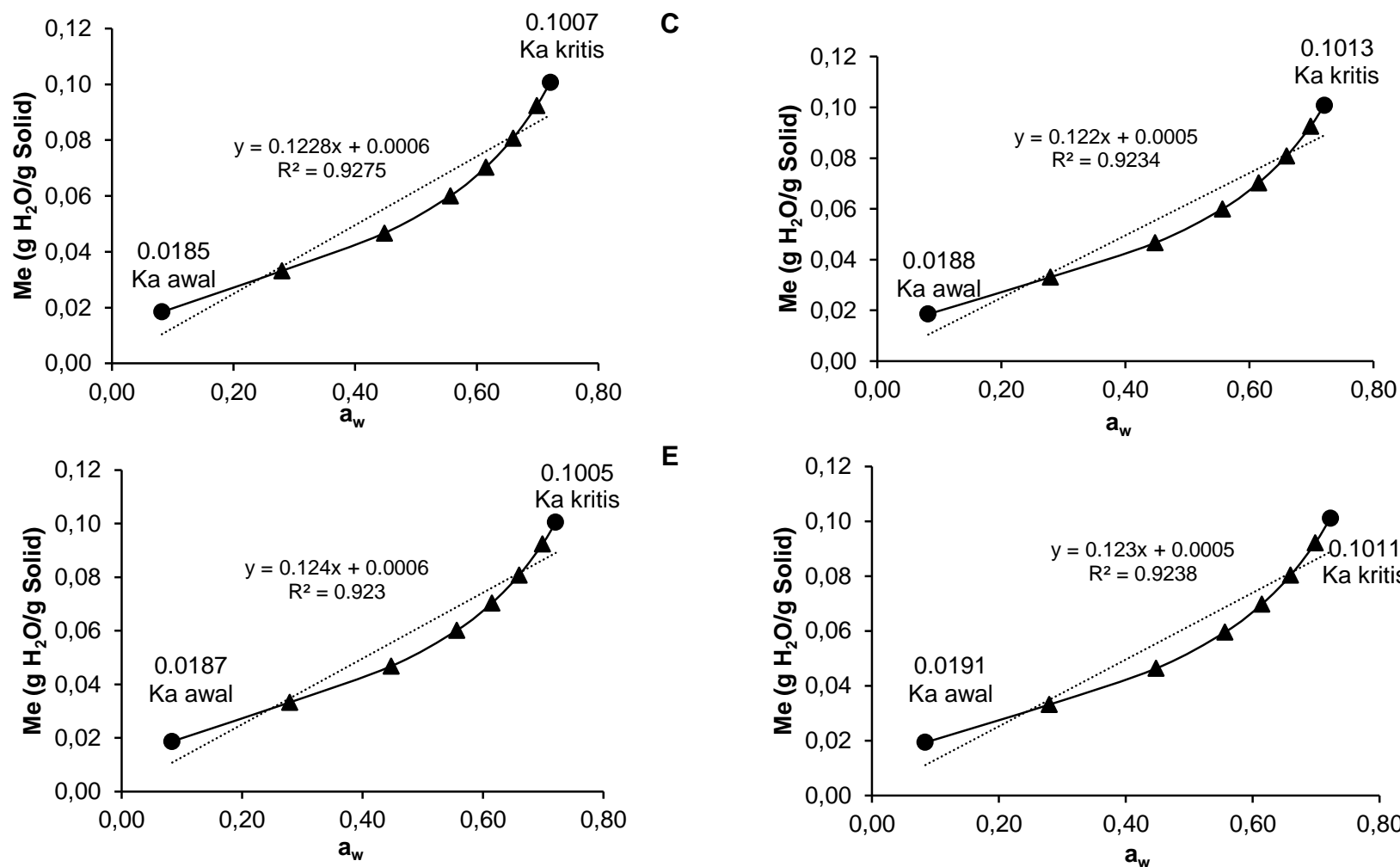

E
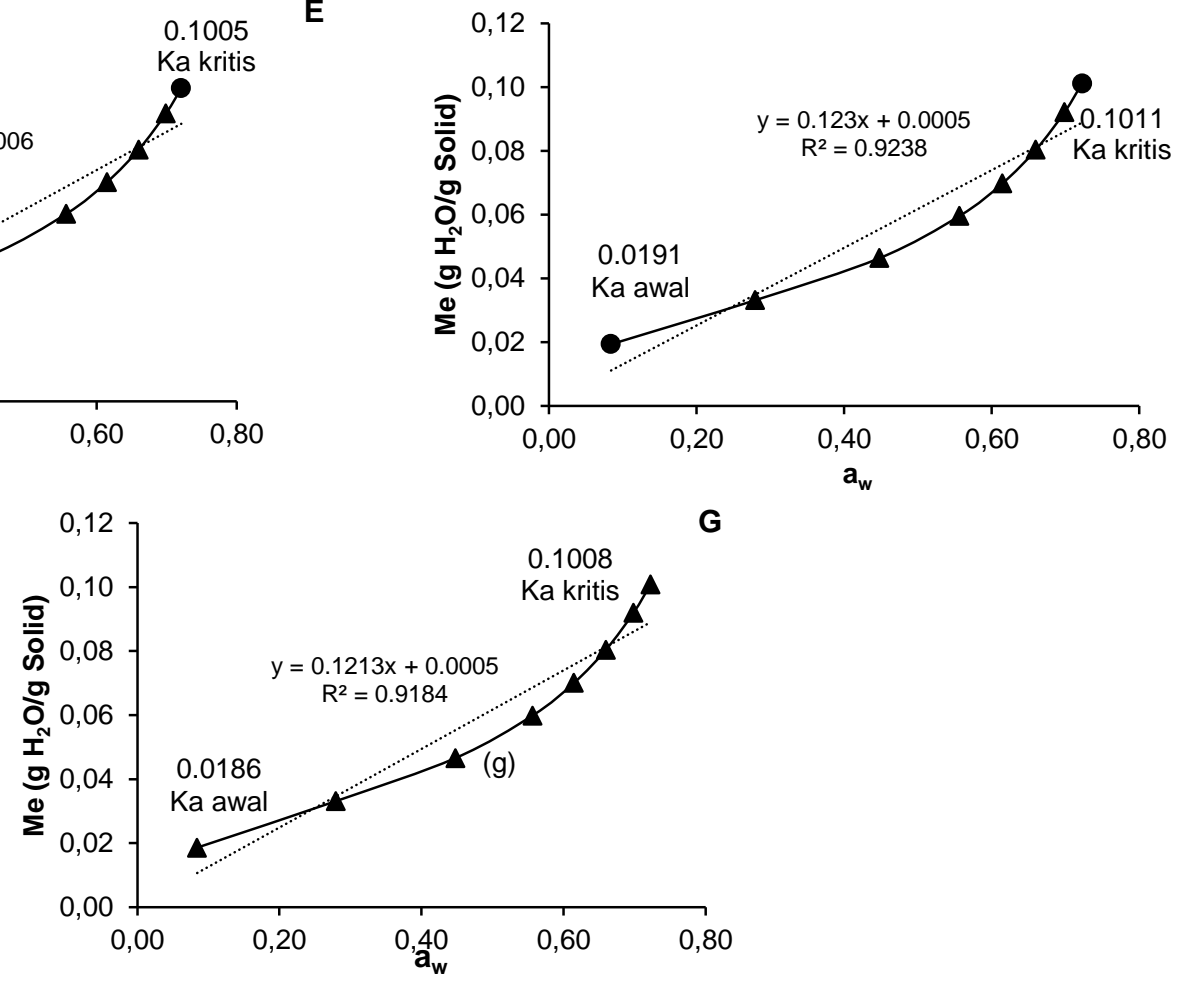

Gambar 3. Penentuan slope b ulangan ke-: (A) 1, (B) 2, (C) 3, (D) 4, (E) 5, (F) 6, (G) 7 


\section{Variabel lain}

Variabel penting lain dalam perhitungan umur simpan yaitu luas kemasan (A) $0.0567 \mathrm{~m}^{2}$, tekanan uap jenuh $\left(\mathrm{P}_{\mathrm{o}}\right)$ suhu penyimpanan $\left(30^{\circ} \mathrm{C}\right) 31.8240 \mathrm{mmHg}$ (Bell dan Labuza 2000), dan permeabilitas uap air (k/x) kemasan metalized plastic laju transmisi uap air yang dapat melewati lapisan kemasan per unit area dalam satu hari pada suhu dan tekanan tertentu, $0.0136 \mathrm{~g} / \mathrm{m}^{2}$.hari.mmHg (Wulandari et al. 2013, Kusnandar et al. 2010).

\section{Hasil perhitungan umur simpan}

Umur simpan keripik kentang pada RH 75 dan 80\% sebesar 22.21 \pm 0.08 dan 11.44 \pm 0.08 bulan (Tabel 2). Hasil perhitungan umur simpan keripik kentang tersebut menunjukkan umur simpan keripik kentang RH tinggi lebih singkat dibanding $\mathrm{RH}$ rendah. Hasil yang sama pada penelitian Anandito et al. (2017) mengenai umur simpan koya ikan. Hasil tersebut menunjukkan RH lingkungan berpengaruh terhadap umur simpan produk pangan. Pada RH tinggi, jumlah uap air lingkungan penyimpanan lebih banyak sehingga penyerapan uap air dari udara ke sampel lebih besar dibandingkan pada RH yang lebih rendah.

\section{Validasi presisi}

Validasi metode merupakan tindakan penilaian terhadap parameter tertentu untuk membuktikan bahwa prosedur tersebut memenuhi persyaratan untuk penggunaannya (Paithankar 2013). Proses validasi metode ini bersifat formal dan sistematis untuk menunjukkan kesesuaian metode dalam memberikan data yang berguna dan konsisten dalam lingkup proses. Tabel 2 menunjukkan bahwa seluruh parameter dan hasil perhitungan umur simpan keripik kentang baik pada RH 75 maupun $80 \%$ berdasarkan tujuh kali ulangan, telah memenuhi kriteria presisi karena menghasilkan nilai RSD yang lebih kecil dari nilai 2/3 RSDH. Oleh karena itu, dapat disimpulkan bahwa prosedur pendugaan umur simpan produk pangan renyah dengan metode kadar air kritis merupakan metode yang valid dan sesuai untuk tujuannya, serta dapat menghasilkan perhitungan umur simpan yang akurat.

\section{KESIMPULAN}

Hasil penelitian menunjukkan bahwa seluruh parameter serta hasil perhitungan umur simpan keripik kentang dari 7 ulangan, telah memenuhi kriteria presisi karena memiliki nilai RSD kurang daari 2/3 RSDH. Umur simpan keripik kentang pada RH 75 dan $80 \%$ sebesar $22.21 \pm 0.08$ dan $11.44 \pm 0.08$ bulan, nilai RSD 0.37 dan $0.74 \%$, serta nilai $2 / 3$ RSDH 0.84 dan $0.92 \%$. Tervalidasinya hasil perhitungan umur simpan ini menunjukkan bahwa prosedur pendugaan umur simpan keripik kentang dengan metode kadar air kritis, merupakan metode yang valid dan sesuai untuk tujuannya, sehingga dapat digunakan secara baku dan tetap oleh laboratorium untuk menduga umur simpan produk pangan renyah dan mampu menghasilkan perhitungan umur simpan yang akurat.

\section{UCAPAN TERIMAKASIH}

Penulis mengucapkan terima kasih kepada Laboratorium Departemen Ilmu dan Teknologi Pangan, Institut Pertanian Bogor, (LDITP IPB), yang telah mendanai penelitian ini.

\section{DAFTAR PUSTAKA}

Aini N, Prihananto V, Wijonarko G. 2014. Karakteristik kurva isotherm air tepung jagung instan. J Agritech 34(1): 50-55.

Akoy EOM, Horsten DV. 2013. Moisture sorption isotherm of mango slices. Int J Agr Food Sci 3(4): 164-170.

Anandito RBK, Siswanti, Purnamayanti L, Sodiq H. 2017. Shelf-life determination of fish koya using critical moisture content approach. Proceedings of the Pakistan Academic of Sciences: B. Life Environ Sci 54(3): 201-206.

Andrade PRD, Lemus MR, Perez CME. 2011. Models of sorption isotherms for food: uses and limitations. $\mathrm{J}$ Vitae 18(3): 325-334.

Bell LN, Labuza TP. 2000. Moisture Sorption Practical Aspects of Isotherm Measurement and Use Second Edition. American Association of Cereal Chemist Inc, Kansas.

Borah PP, Nayak PK. 2013. Quality characteristics of dried jahaji banana chips after deep fat frying. Int $\mathbf{J}$ Agric Food Sci Technol 4(9): 901-908.

[BSN] Badan Standarisasi Nasional. 1992. SNI 01-28911992: Cara Uji Makanan dan Minuman. BSN, Jakarta.

[BSN] Badan Standarisasi Nasional. 1996. SNI 01-40311996: Keripik Kentang. BSN, Jakarta.

Budijanto S, Sitanggang AB, Silalahi BE, Murdiati W. 2010. Penentuan umur simpan seasoning menggunakan metode accelerated shelf life testing (ASLT) dengan pendekatan kadar air kritis. J Teknologi Pertanian 11(2): 71-77.

Delgado JMPQ, da Silva MV. 2010. A mathematical model to predict moisture uptake of dry products packaged individually in flexible films. J Defect Diffusion Forum 297-310: 1250-1255. DOI: 10.4 028/www.scientific.net/DDF.297-301.1250.

Goula AM, Karapantsios TD, Achilias DS, Adamopoulos KG. 2008. Water sorption isotherms and glass transition temperature of spray dried tomato pulp. J Food Eng 85(1): 73-83. DOI: 10.1016/j.jfoodeng. 2007.07.015.

Greenspan L. 1977. Humidity fixed points of binary saturated aqueous solutions. J Res Nat Bureau Standards: A Phys Chem 81A:89-96. DOI: 10.6028/jres.081A.011. 
Harmita. 2004. Petunjuk pelaksanaan validasi metode dan cara perhitungannya. Majalah Ilmu Kefarmasian 1(3): 117-135. DOI: 10.7454/psr.v1i3.3375.

Herawati H. 2008. Penentuan umur simpan pada produk pangan. J Litbang Pertanian 27(4): 124-130.

Hutasoit N. 2009. Penentuan Umur Simpan Fish Snack (Produk Ekstrusi) Menggunakan Metode Akselerasi dengan Pendekatan Kadar Air Kritis dan Metode Konvensional. [Skripsi]. Bogor: Fakultas Perikanan dan Ilmu Kelautan, Institut Pertanian Bogor.

[ICH] International Conference of harmonisation of Technical Requirements for registration of Pharmaceuticals for Human Use. 2005. Validation of analytical procedure: test and methodology Q2. http://www.ich.org/fileadmin/Public/Web_Site/ICH _Products/Guidelines/Quality/Q2_R1/Step4/Q2_R1 _Guideline.pdf.

Irpatrawan U. 2009. Shelf-life simulation of packaged rice crackers. J Food Quality 32: 224-239. DOI: 10.1111/j.1745-4557.2009.00247.x

Jakubczyk E, Marzec A, Lewicki PP. 2008. Relationship between water activity of crisp bread and its mechanical properties and structure. Polish J Food Nutr Sci 58(1): 45-51.

Khalishi Z. 2011. Karakterisasi dan Formulasi Rengginang Tepung Ikan Tembang (Sardinella fimbriata). [Skripsi]. Bogor: Fakultas Perikanan dan Ilmu Kelautan, Institut Pertanian Bogor.

Kilcast D, Subramaniam P. 2000. Introduction. Kilcast D, Subramaniam P, editor. The Stability and Shelf-Life of Food, hal 1-19. Woodhead Publishing, Cambridge. ISBN 0-8493-0857-7. DOI: 10.1533/978 1855736580.

Koc B, Yilmazer MS, Balkir P, Ertekin FK. 2010. Moisture sorption isotherms and storage stability of spray-dried yoghurt powder. J Dry Technol 28: 816822. DOI: 10.1080/07373937.2010.485083.

Kusnandar F, Adawiyah DR, Fitria M. 2010. Pendugaan umur simpan produk biskuit dengan metode akselerasi berdasarkan pendekatan kadar air kritis. J Teknol Industri Pangan 21(2): 117-123.

Kwak HS, Chang YH, Lee Y. 2015 Estimation of crispness and consumer acceptance of fried potato chips by mechanical and acoustic measurements. Int J Food Sci Technol 50: 500-506. DOI: 10.1111/ ijfs. 12696.

Labuza TP. 1982. Shelf Life Dating of Food. Food and Nutrition Press, Trumbull (US).

Lestari S, Muharfiza. 2015. Karakterisasi fisikokimia kerupuk melinjo sebagai upaya diversifikasi produk olahan melinjo. Prosiding Seminar Nasional Masyarakat Biodiversitas Indonesia: Manajemen Biodiversitas bagi Kemandirian Bahan Pangan, Bahan Obat dan Bahan Baku Industri 1(1): 10-11. DOI: $10.13057 / \mathrm{psnmbi} / \mathrm{m010122.}$
Lutovska M, Mitrevski V, Pavkov I, Babic M. Mijakovski V, Geramitcioski T, Stamenkovic Z. 2017. Different methods of equilibrium moisture content determination. J Proces Energy Agr 21(2): 91-96. DOI: 10.5937/JPEA1702091L.

Manikantan MR, Sharma R, Kasturi R, Varadharaju N. 2012. Storage stability of banana chips in polypropylene based nanocomposite packaging films. J Food Sci Technol 51(11): 2990-3001. DOI: 10.1007/s13197-012-0839-0.

Meher JM, Nayak PK. 2015. Effect of pre- drying and frying kinetics of sweet potato (Ipomoea batatas 1.) chips. Int Quarterly J Life Sci 10(2): 521-525.

Nurtama B, Lin J. 2010. Moisture sorption isotherm characteristics of taro flour. World J Dairy Food Sci 5(1): 01-06.

Paithankar HV. 2013. HPLC method validation for pharmaceuticals: a review. Int J Universal Pharm Bio Sci 2(4): 229-240.

Panjagari NR, Singh AK, Gangluy S, Indumati KP. 2015. Beta-glucan rich composite flour biscuits: modelling of moisture sorption isotherms and determination of sorption heat. J Food Sci Technol 52(9): 5497-5509. DOI: $10.1007 / \mathrm{s} 13197-014-1658-2$.

Romani S, Tappi S, Balestra F, Estrada MTR, Siracusa V, Rocculi P, Rosa MD. 2014. Effect of different new packaging materials on biscuit quality during accelerated storage. J Sci Food Agr 1-11. DOI: 10.1002/jsfa.6888.

Sakac M, Pestoric M, Mandic A, Misan A, Nedeljkovic N, Jambrec D, Jovanov P, Lazic V, Pezo L, Sedej I. 2016. Shelf-life prediction of gluten-free ricebuckwheat cookies. J Cereal Sci 69(2016): 336-343. DOI: $10.1016 /$ j.jcs.2016.04.008.

Segovia PG, Ramos AMU, Fiszman S, Monzo JM. 2016. Effects of processing conditions on the quality of vacuum fried cassava chips (Manihot esculenta Crantz). J LWT-Food Sci Technol DOI: 10.1016/ j.lwt.2016.02.014.

Setyawan AD, Sugiyarto, Solichatun, Susilowati A. 2013. Review: Physical, physical chemistries, chemical and sensorial characteristics of the several fruits and vegetables chips produced by lowtemperature of vacuum frying machine. J Nusantara Bioscience 5(2): 86-103. DOI: 10.13057/nusbio sci/n050206.

Tunick MH, Onwulata CI, Thomas AE, Phillips MH, Mukhopadhyay S, Sheen S, Liu CK, Latona N, Pimentel MR, Cooke PH. 2013. Critical evaluation of crispy and crunchy textures: a review. Intl J Food Properties 16: 949-963. DOI: 10.1080/10942912.20 11.573116.

Velickova E, Winkelhausen E, Kuzmanova S. 2014. Physical and sensory properties of ready to eat apple chips produced by osmo-convective drying. J Food 
Sci Technol 51(12): 3691-3701. DOI: $10.1007 / \mathrm{s} 13$ 197-013-0950-х.

Widjajaseputra AI. 2012. Relation of moisture distribution and texture of rice-based foods: a perspective. Int Food Res J 19(3): 1275-1278.

Wijaya IMAS, Suter IK, Yusa NM. 2014. Karakteristik isotermis sorpsi air dan umur simpan ledok instan. J Agritech 34(1): 29-35.

Wulandari A, Waluyo S, Novita DD. 2013. Prediksi umur simpan kerupuk kemplang dalam kemasan plastic polipropilen beberapa ketebalan. J Teknik Pertanian
Yang J, Martin A, Richardson S, Wu CH. 2017. Microstructure investigation and its effects on moisture sorption in fried potato chips. J Food Eng 214: 117-128. DOI: 10.1016/j.jfoodeng.2017.06.034.

Zulfahmi AN, Swastawati F, Romadhon. 2014. Pemanfaatan daging ikan tenggiri (scomberomorus commersoni) dengan konsentrasi yang berbeda pada pembuatan kerupuk ikan. J Pengolahan Bioteknol Hasil Perikanan 3(4): 133-139.

JMP-03-18-09-Naskah diterima untuk ditelaah pada 12 Maret 2018. Revisi makalah disetujui untuk dipublikasi pada 12 April 2018. Versi Online: http://journal.ipb.ac.id/index.php/jmpi 